\title{
RECLAMATION OF MARGINAL LANDS USING RARE ENERGY CROPS
}

\section{Maksym Kulyk ${ }^{1}$ \\ Dmytro D'omin ${ }^{2}$}

Ilona Rozhko ${ }^{3}$

DOI: https://doi.org/10.30525/978-9934-26-077-3-27

Abstract. The purpose of the paper is to determine the impact of the species of energy crops on biomass yields and the possibility of their involvement in the reclamation of contaminated areas. This is especially important from the point of view of the rational use of land for energy crops cultivation. Methodology. The research object is the processes of growth and development of plants, the peculiarities of the yield formation of energy crops biomass depending on the species traits and growing conditions. The research subject is the following energy crops: Big Bluestem, Indiangrass and Columbus Grass as well as the plant biometric indicators, biomass yield and energy efficiency of biomass production of energy crops (2016-2020). The results of research showed the variability of biometric parameters of energy crops. Over the research years, the dry biomass yield of Indiangrass was $8.9 \mathrm{t} / \mathrm{ha}$ in the first year, $10.1 \mathrm{t} / \mathrm{ha}$ in the second year and $14.9 \mathrm{t} / \mathrm{ha}$ in the third year, Big Bluestem - varied within 4.4-9.3 t/ha. Columbus Grass dry biomass increased from $11.4 \mathrm{t} / \mathrm{ha}$ ( $1^{\text {st }}$ year) to $14.9 \mathrm{t} / \mathrm{ha}$ ( $2^{\text {nd }}$ year) to $18.0 \mathrm{t} / \mathrm{ha}$ ( $3^{\text {rd }}$ year). The developed model for the creation of artificial phytocenoses will allow land reclamation using energy crops based on agroecological monitoring and justification when growing energy crops. Perennial cultivation of Columbus Grass and Indiangrass provided the highest coefficient of energy efficiency (at a level or more than 3.0), which is typical for average efficiency of biomass production. Therefore,

\footnotetext{
${ }^{1}$ Doctor of Agricultural Sciences,

Professor at Department of Breeding, Seed Production and Genetics,

Poltava State Agrarian Academy, Ukraine

${ }^{2}$ Postgraduate student at the Department of Breeding, Seed Production and Genetics,

Poltava State Agrarian Academy, Ukraine

${ }^{3}$ Assistant Lecturer at the Department of Breeding, Seed Production and Genetics,

Poltava State Agrarian Academy, Ukraine
} 
Indiangrass and Columbus Grass are recommended to be grown in order to reclaim marginal lands and obtain sustainable plant raw materials. Big Bluestem is recommended to be grown only as a companion crop of stand of grass. Furthermore, energy crops must be cultivated on the basis of ecological and adaptive technology elements, taking into account the defined territorial conditions. For the conditions of Ukraine, this complex will make it possible to reduce the negative impact on the environment as well as to obtain the stable yields of various biomass for its further processing and energy conversion.

\section{Introduction}

In the period of a rapid reduction of the world reserves of non-renewable energy resources, mankind faced the problem of finding alternative energy sources to satisfy their own needs and the existence of civilization as a whole. Along with food security, every country strives for energy independence. Ukraine is no exception; its priority at this stage of development is to find ways to attract new sources to the fuel and energy complex (FEC) of the country.

In addition, the environmental impact of anthropogenic activities is increasing and irreversible climate changes are taking place on a planetary scale. This, in turn, contributes to an increase in the trend of the average daily air temperature and deterioration of the water regime of soils. Frequent droughts followed by heavy rains are often observed $[1 ; 2]$.

Soil and climatic conditions of almost all regions in Ukraine are favorable for growing perennial energy plants. This is especially true for plants of the C4 group, which are able to intensively accumulate solar energy during their growing season. Besides, energy crops are cultivated using a simplified cultivation technology on marginal lands. Marginal lands are unproductive lands, not farmland. Energy crops do not require significant application of fertilizers and pesticides. They prevent soil erosion due to the dense phytocenosis and strong root system and have phytoremediation properties. These traits of energy crops contribute to the preservation and improvement of agro-ecosystems [3-5]. This enables to claim about the reasonability of growing energy crops on lands taken out of crop rotation. There are from 3 to 5 million hectares of such lands according to statistics in Ukraine [6].

Switchgrass, Miscanthus, Big Bluestem, Indiangrass and Columbus Grass are the best energy crops for soil reclamation. These plants are 
introduced cereals, have good adaptive properties under the conditions of Ukraine [7; 8]. They are able to form a significant biomass during a longterm growing cycle $[9 ; 10]$. Therefore, the scientific substantiation of energy crops cultivation on marginal lands in order to improve the environment is becoming highly important.

\section{Emergence of preconditions for the research and problem statement}

Today, there are various researches on the study of energy crops in Ukraine. They cover a wide range of issues: environmental, biofuel, breeding and seed production. Seed material of energy crops is being studied taking into account the conditions of its cultivation [11]. The agrobiological peculiarities of yield formation, quality of switchgrass seed [12] and biomass potential of energy crops are also being investigated [13]. The ways of using energy crops biomass for biofuel production are being justified as well as the innovative ways of energy transformation are being developed [14; 15].

Along with rapid development of alternative energy sources in the world, Ukraine remains a country that only partially meets its own needs. Our country has little supply of traditional energy resources and has to import about $65 \%$ of energy $[16 ; 17]$.

Features of natural landscapes and peculiarities of marginal lands reclamation should be studied in order to create artificial phytocenoses. This involves further selection of promising plant species and their use as the components for phytomelioration. There is an urgent need to purify the soil from various types of contamination [18].

Thus, the experiments of Ukrainian scientists [19] showed that plants of the Poaceae family, which grow in natural phytocenoses on contaminated soils, have the potential to be used for soil purification. An innovative way of soil purification with the help of switchgrass in mutual cultivation with lupine is proposed in order to solve the problem of soil pollution [20].

The agrotechnological components of the phytocenosis must be improved to create highly productive energy crops plantations. This involves the use of energy crops with legumes as the components for phytomelioration [21].

The use of degraded or contaminated land partially solved the problem of using farmland to obtain vegetable raw materials for energy purposes. The fast-growing plant species provide the maximum effect of phytoremediation 
on contaminated lands. A variety of energy crops contributes to the production of biofuels and the cleaning of contaminated areas. Restoration of functional and ecosystem properties of contaminated lands will return them to the agricultural use. In the future, energy crops will be able to solve both energy and environmental problems [22].

It was determined $[23 ; 24]$ that under the conditions of heavy metal contamination of the territory of TPP (thermal power plants) ash dumps, a small group of species belonging to the families Poaceae, Asteraceae and Apiaceae had the leading positions in the groups. Plants from these families are highly resistant to heavy metals. A mixture of Columbus grass (Sorghum almum parodi) + sainfoin showed one of the best indicators in the phytocenosis restoration.

The list of energy crops suitable for phytocenosis restoration is determined. They are switchgrass, miscanthus giganteus, sorghum crops, etc. [25].

Mutual cultivation of miscanthus giganteus and lupine $(12.2 \mathrm{t} / \mathrm{ha})$ produced the highest dry biomass yield according to the research conducted in the Forest-Steppe. This was significantly higher (by $2.9 \mathrm{t} / \mathrm{ha}$ ) compared to single-species crops and by $2.4 \mathrm{t} /$ ha more than cultivation with clover and by $3.5 \mathrm{t} /$ ha more than variants with alfalfa [26].

Researches of A. J. Ashworth, at all. [27] established a positive dynamics of increasing the sustainability of feed and bio raw materials production on mutual crops. The dynamics of soil organic matter increase was determined when switchgrass was cultivated with red clover (Trifolium pratense L.), hairy vetch (Vicia villosa L.), perennial clover (Trifolium repens L.), arrowleaf clover (Trifolium vesiculosum L.) and other legumes.

So, the research on environmental issues is of high importance. This is especially important from the point of view of the rational use of land for energy crops cultivation.

\section{Research aim and tasks}

The aim of the research is to determine the impact of the species of energy crops on biomass yields and the possibility of their involvement in the reclamation of contaminated areas.

The research tasks are the following:

1. To determine the variability of biometric indicators of energy crops depending on growing conditions. 
2. To justify the ways of increasing the yield of energy crops biomass.

3 . To develop a scheme for the creation of artificial phytocenoses and land reclamation using energy crops.

The final stage of the research program included determination of energy efficiency of energy crops, as well as development of a reclamation model.

The research object is the processes of growth and development of plants, the peculiarities of the yield formation of energy crops biomass depending on the species traits and growing conditions.

The research subject is the following energy crops: Big Bluestem, Indiangrass and Columbus Grass as well as the plant biometric indicators and biomass yield.

During the experiment, we used general scientific methods and special methods, including: laboratory - to determine the variability of quantitative indicators of plants (biometric indicators); field - to determine the interaction between research subject and object; weight - determination of biomass yield and modeling. Mathematical and statistical analysis of the obtained research results was also used in order to objectively assess the obtained data.

Field experiments were established in accordance with the requirements of the research methodology in agronomy [28].

In our research, we carried out observations, accounting and analysis in accordance with generally accepted and special scientific methods and recommendations for production [29-31].

Yields of the so-called "raw" (green mass) and "dry" plant biomass were determined after the end of the growing season. Biomass was harvested manually from each experimental plot $[32 ; 33]$.

The research results were analyzed according to statistical and mathematical methods by the analysis of variance using the computer program "Statistica-6.0" [34; 35].

Energy evaluation of the effectiveness of energy crops cultivation was performed according to the author's methodology [36].

\section{Description of rare energy crops}

We studied the following energy crops: Indiangrass, Big Bluestem and Columbus Grass (black).

Indiangrass (Sorghastrum nutans (L.) Nash) [37] is a native perennial grass that is used to prevent erosion, to landscape territories and provide 
food and shelter for wildlife. Indiangrass is a warm-season cereal in the tallgrass prairie ecosystem of North America. The natural habitat of plants is open fields and meadows. Plant height is $1.8-3.2 \mathrm{~m}$; the minimum depth of root penetration is $60-70 \mathrm{~cm}$ (Figure 1).

Indiangrass plants are adapted to soils with deep moisture, ranging from heavy loamy and loamy sands with a $\mathrm{pH}$ range of 4.8 to 8.0. It has a medium resistance to salinity and drought, adapted to periodic burning, and survives, sprouting

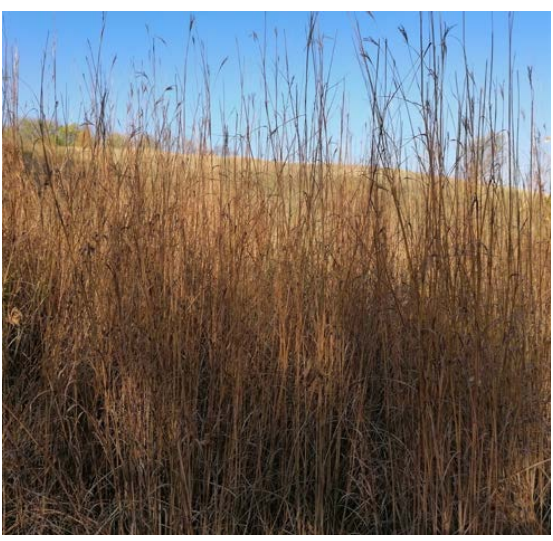

Figure 1. Indiangrass

(Sorghastrum nutans (L.) Nash) from underground rhizomes (rhizome). Yield of Indiangrass biomass reaches up to $12-15 \mathrm{t} / \mathrm{ha}$.

The seeding rate of Indiangrass for natural conditions is $4-5 \mathrm{~kg} / \mathrm{ha}$; in a mixture of $10-50 \%$ is about 350,000 seeds per $1 \mathrm{~kg}$. The number of years of cultivation on the plot is up to 15; the number of years to the maximum biomass yield from 1 ha is three years. This plant can become invasive in some regions or habitats and can displace desired vegetation if not managed properly [38].

Big Bluestem (Andropogon gerardii Vitman) is a perennial grass that is used for erosion control. It grows in sand and gravel quarries, in mountain quarries and on roadsides. Big Bluestem is used as a raw material for the production of biofuels and can be used as quality forage for livestock. The grass improves biodiversity [39].

Big Bluestem is one of the most common species in the tallgrass prairie ecosystem of North America. The natural habitat of Big Bluestem phytocenoses is open fields and meadows. Plant height is $1.8-2.5 \mathrm{~m}$; the minimum depth of root penetration is $50 \mathrm{~cm}$ [40], Figure 2

Big Bluestem is tolerant to a wide range of soil conditions and moisture levels; it has high drought resistance and moderate salt tolerance. Seeding rate for natural conditions is $4.5-6 \mathrm{~kg} / \mathrm{ha}$; in a mixture of $10-50 \%$ is 288,000 seeds per $1 \mathrm{~kg}$. Biomass yield is $10-12 \mathrm{t} / \mathrm{ha}$. The number of years of 


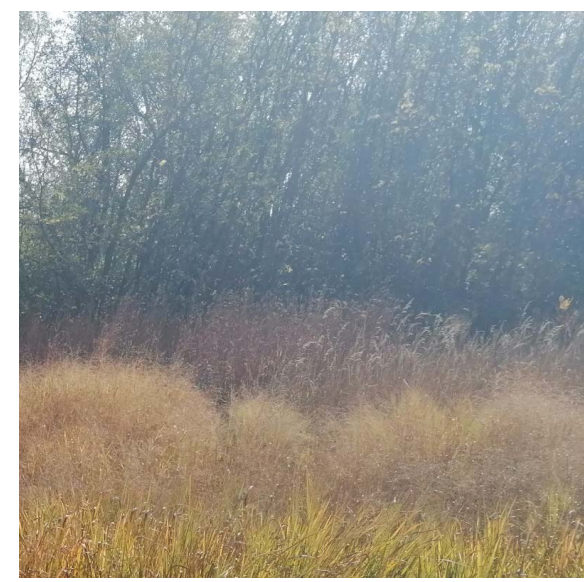

Figure 2. Big Bluestem

(Big Bluestem, Andropogon gerardii Vitman)

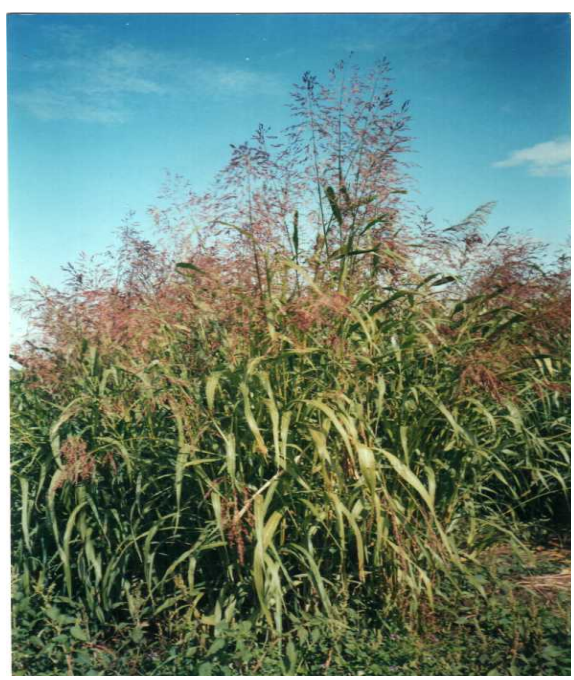

Figure 3. Columbus Grass

(Columbus Grass, Sorghum almum Parodi) cultivation on the plot is $12-14$; the number of years to the maximum biomass yield from 1 ha is three years [42].

Big Bluestem for biofuels should be harvested in autumn to minimize the loss of dry biomass, as it tends to lodge during winter. Some studies showed that Big Bluestem biomass has lower ash content than other specialized energy crops [43].

Columbus Grass (Sorghum almum Parodi) is a frost resistant crop that provides high biomass and seed yields and has a proven cultivation technology [44]. Plant height is 2.8-3.5 m; minimum depth of root penetration is $70-80 \mathrm{~cm}$; high drought resistance; moderate salt tolerance [45], Figure 3.

Seeding rate of sorghum for natural conditions is $8.5-10 \mathrm{~kg} / \mathrm{ha}$; in a mixture has not been studied. Biomass yield is $18-20 \mathrm{t} / \mathrm{ha}$. The number of years of cultivation on the plot is up to 7; the number of years to the maximum biomass yield from 1 ha is two years [46].

Organogenesis stages of energy crops of the Poaceae family. It is established that the studied energy crops are perennial plants that go through all stages of growth and development in more than one calendar year. The phenological 
phases of growth and development of such crops are similar: germination, tillering of plants, stem elongation, panicle formation, flowering, formation and maturation of seeds, the end of the growing season [47]. The growing season of energy crops are divided into 3 main stages, the duration of each is different and has its own characteristics. "The first stage, also called the stage of vegetative growth" is a period from germination to the beginning of the formation of generative organs on the stem (panicles, caryopsis). "The second stage, called the reproductive one" lasts from the time the panicles appear at the top of the stem until flowering. "The third stage, which is called "grain filling" lasts from plants flowering to the completion of dry matter accumulation in the caryopsis [48].

Energy crops (Sorghastrum nutans, Indiangrass and Columbus Grass) belong to the $\mathrm{C} 4$ group. These are typical warm-season, heat- and droughtresistant plants. The seeds germinate at a temperature of $10-12^{\circ} \mathrm{C}$. The minimum and critical soil temperature for seedlings is at or below $0{ }^{\circ} \mathrm{C}$. The maximum temperature for the vegetation of these crops is $30-35^{\circ} \mathrm{C}$; they even can withstand heat up to $40^{\circ} \mathrm{C}[49 ; 50]$.

\section{Formation of biometric indicators of energy crops}

Over the research years (2016-2020), significant variability of plant biometric indicators was established for energy crops cultivation on marginal soils. This characteristic was manifested in indicators of height and density of stems (Tables 1-2, Figures 1-2).

Table 1

Plant height of energy crops (cm), 2016-2020

\begin{tabular}{|l|c|c|c|c|}
\hline \multirow{2}{*}{\begin{tabular}{c}
\multirow{2}{*}{$\begin{array}{c}\text { Energy crop } \\
\text { (factor A) }\end{array}$} \\
\cline { 2 - 4 }
\end{tabular}} & $\begin{array}{c}\text { I } \\
\mathbf{( 2 0 1 6 - 2 0 1 8 )}\end{array}$ & $\begin{array}{c}\text { II } \\
\mathbf{( 2 0 1 7 - 2 0 1 9 )}\end{array}$ & $\begin{array}{c}\text { III } \\
\mathbf{( 2 0 1 8 - 2 0 2 0 )}\end{array}$ & \multirow{2}{*}{ Average } \\
\hline Indiangrass & 111.5 & 163.4 & 155.7 & 143.5 \\
\hline Big Bluestem & 37.3 & 72.5 & 91.1 & 67.0 \\
\hline Columbus Grass & 115.9 & 207.4 & 237.9 & 187.1 \\
\hline Year average & 88.2 & 147.8 & 161.6 & 132.5 \\
\hline LSD 05 (factor A) & 24.5 & 17.3 & 20.1 & 18.8 \\
\hline LSD 05 (factor B) & - & - & - & 25.7 \\
\hline LSD05 (factor A and B) & - & - & - & 16.4 \\
\hline
\end{tabular}


Height of Indiangrass plants varied from $111.5 \mathrm{~cm}$ (in the first year of vegetation) to $155.7 \mathrm{~cm}$ (in the third year of vegetation). In the second year of crop life, height of the stems reached to $163.4 \mathrm{~cm}$ on average. As a result, the average height of plants over three years was $143.5 \mathrm{~cm}$.

Energy crop Big Bluestem showed slightly lower indicators of stem height. The trend of increasing height of Big Bluestem plants reached indicators from $37.3 \mathrm{~cm}$ in the first year to $91.1 \mathrm{~cm}$ in the third year of vegetation. The annual increase in linear growth of plants ranged from 18.6 to $35.3 \mathrm{~cm}$.

Columbus Grass plants showed a significant increase in plant height by $30.5-91.5 \mathrm{~cm}$. Over the years of research, height of stems varied from 115.9 to $237.9 \mathrm{~cm}$.

The density of stems of energy crops varied from 0.5 to 2.2 million pcs/ha (Table 2).

Table 2

The density of stems of energy crops (million pcs/ha), 2016-2020

\begin{tabular}{|l|c|c|c|c|}
\hline \multirow{2}{*}{ Energy crop (factor A) } & \multicolumn{3}{|c|}{ Year of vegetation (factor B) } & \multirow{2}{*}{ Average } \\
\cline { 2 - 4 } & $\begin{array}{c}\text { I } \\
\mathbf{( 2 0 1 6 - 2 0 1 8}\end{array}$ & $\begin{array}{c}\text { II } \\
\mathbf{( 2 0 1 7 - 2 0 1 9 )}\end{array}$ & $\begin{array}{c}\text { III } \\
\mathbf{( 2 0 1 8 - 2 0 2 0 )}\end{array}$ & \\
\hline Indiangrass & 0.9 & 1.4 & 2.2 & 1.5 \\
\hline Big Bluestem & 0.5 & 0.7 & 0.8 & 0.7 \\
\hline Columbus Grass & 1.4 & 2.0 & 2.2 & 1.9 \\
\hline Year average & 0.9 & 1.4 & 1.7 & 1.3 \\
\hline LSD 05 (factor A) & 0.2 & 0.3 & 0.3 & 0.2 \\
\hline LSD 05 (factor B) & - & - & - & 0.3 \\
\hline LSD 05 (factor A and B) & - & - & - & 0.2 \\
\hline
\end{tabular}

The density of stems of Indiangrass plants ranged from 0.9 (in the first year of vegetation) to 2.2 million pcs/ha (in the third year). In the second year of the crops life, the stem density averaged 1.4 million $\mathrm{pcs} / \mathrm{ha}$. As a result, the average plant density for three years was 1.5 million pcs/ha. There is a tendency of annual growth of stem density by $0.5-0.8$ million plants per 1 hectare.

Big Bluestem showed significantly lower indicators of stem density. The increase of Big Bluestem plant density during the growing season was from 0.5 in the first year to 0.8 million $\mathrm{pcs} / \mathrm{ha}$ in the third growing year, and 
0.7 million $\mathrm{pcs} / \mathrm{ha}$ was in the second growing season. The annual increase in the number of plants ranged from 0.1 to 0.2 million $\mathrm{pcs} / \mathrm{ha}$.

For the Columbus Grass phytocenosis, a significant overcrowding of crops was established - from 1.4 to 2.2 million $\mathrm{pcs} / \mathrm{ha}$ with the annual increase of this indicator from 0.2 to 0.6 million $\mathrm{pcs} / \mathrm{ha}$.

On average over the research years, height of Indiangrass $(187.1 \mathrm{~cm})$ and Columbus Grass $(143.5 \mathrm{~cm})$ plants was the largest, Big Bluestem plants were the lowest $(67.0 \mathrm{~cm})$. According to the indicator of stem density, we received the following results: $1.9 ; 1.5$ and 0.7 million $\mathrm{pcs} / \mathrm{ha}$, respectively by crops (Figure 4).

So, Indiangrass and Columbus Grass were distinguished according to the quantitative indicators of plants (stem height and density).

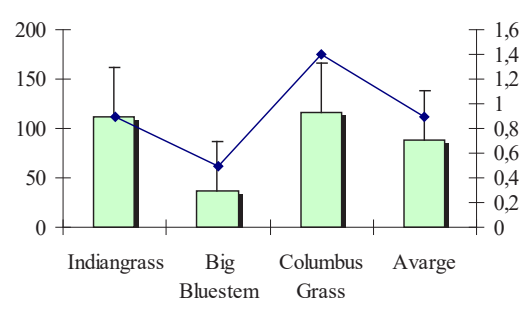

$\square$ Plant height, cm $\longrightarrow$ Number of plants, mil.unit./ha

The first year of vegetation

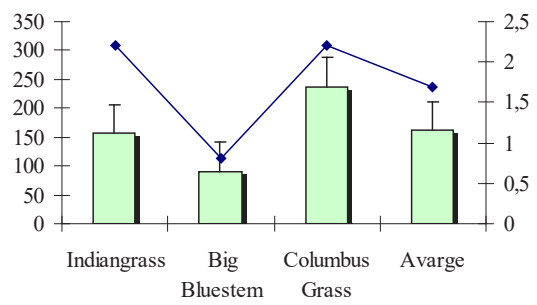

$\square$ Plant height, cm

— Number of plants, mil.unit./ha

The third vegetation year

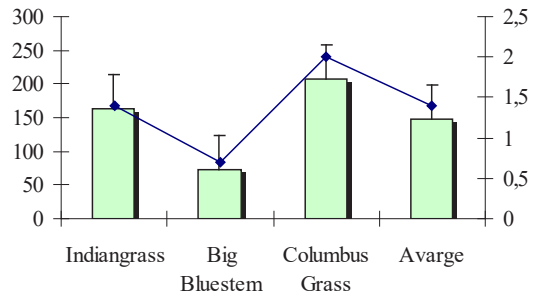

$\longrightarrow$ Plant height, cm $\multimap$ Number of plants, mil.unit./ha

The second year of vegetation

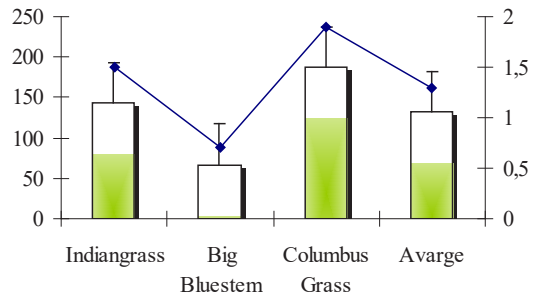

$\square$ Plant height, cm $\longrightarrow$ Number of plants, mil.unit./ha

Average over the years

Figure 4. Height and stem density of energy crops over the research years and on average, 2016-2020 


\section{Yield of energy crops biomass}

Species characteristics, along with quantitative indicators of energy crops affected yield of biomass obtained from the field (Table 3 ).

Table 3

Yield of raw biomass of energy crops (t/ha), 2016-2020

\begin{tabular}{|l|c|c|c|c|}
\hline \multirow{2}{*}{ Energy crop (factor A) } & \multicolumn{3}{|c|}{ Year of vegetation (factor B) } & \multirow{2}{*}{ Average } \\
\cline { 2 - 4 } & $\begin{array}{c}\text { I } \\
\mathbf{( 2 0 1 6 - 2 0 1 8 )}\end{array}$ & $\begin{array}{c}\text { II } \\
\mathbf{( 2 0 1 7 - 2 0 1 9 )}\end{array}$ & $\begin{array}{c}\text { III } \\
\mathbf{( 2 0 1 8 - 2 0 2 0 )}\end{array}$ & \\
\hline Indiangrass & 10.1 & 12.1 & 16.2 & 12.8 \\
\hline Big Bluestem & 5.3 & 9.4 & 10.7 & 8.5 \\
\hline Columbus Grass & 13.2 & 19.4 & 26.0 & 19.5 \\
\hline Year average & 9.5 & 13.6 & 17.6 & 13.6 \\
\hline LSD 05 (factor A) & 1.7 & 2.5 & 6.5 & 5.1 \\
\hline LSD 05 (factor B) & - & - & - & 4.2 \\
\hline LSD 05 (factor A and B) & - & - & - & 2.0 \\
\hline
\end{tabular}

Over the research years, an increase in the trend of "raw" (green) biomass of Indiangrass from 10.1 to $16.2 \mathrm{t} / \mathrm{ha}$, on average to $12.8 \mathrm{t} / \mathrm{ha}$ was observed. The annual biomass growth reached from 2.0 to $4.1 \mathrm{t} / \mathrm{ha}$.

Big Bluestem produced low yields of both green and dry biomass. Over the research years, an increase in the trend of "raw" (green) biomass from 3.3 to $10.7 \mathrm{t} / \mathrm{ha}$ was noted. The annual biomass growth reached from 1.3 to $4.1 \mathrm{t} / \mathrm{ha}$.

Over the research years, the yields of Columbus Grass green mass increased from 9.5 to $17.6 \mathrm{t} / \mathrm{ha}$. The annual stable growth of green biomass in the second vegetation year was $4.1 \mathrm{t} / \mathrm{ha}$ compared to the first year, and in the third vegetation year at a level of $4.0 \mathrm{t} / \mathrm{ha}$ in comparison to the second year. Taking into account the moisture content in the aboveground vegetative phytomass, the dry matter content and biomass yield of energy crops were determined (Table 4).

Over the research years, the dry biomass yield of Indiangrass was $8.9 \mathrm{t} / \mathrm{ha}$ in the first year, $10.1 \mathrm{t} / \mathrm{ha}$ in the second year and $14.9 \mathrm{t} / \mathrm{ha}$ in the third year, $11.3 \mathrm{t} / \mathrm{ha}$ was on average over the years.

The yield of Big Bluestem dry biomass in the first year was $4.4 \mathrm{t} / \mathrm{ha}$, $8.3 \mathrm{t} / \mathrm{ha}$ was in the second year and $9.3 \mathrm{t} / \mathrm{ha}$ was in the third year, $7.3 \mathrm{t} / \mathrm{ha}$ was on average over the years. 
Yield of dry biomass of energy crops (t/ha), 2016-2020

\begin{tabular}{|l|c|c|c|c|}
\hline \multirow{2}{*}{\begin{tabular}{c}
\multirow{2}{*}{$\begin{array}{c}\text { Energy crop } \\
\text { (factor A) }\end{array}$} \\
\cline { 2 - 4 }
\end{tabular}} & \multicolumn{3}{|c|}{ Year of vegetation (factor B) } & \multirow{2}{*}{ Average } \\
\hline (2016-2018 $)$ & $\begin{array}{c}\text { II } \\
\mathbf{( 2 0 1 7 - 2 0 1 9 )}\end{array}$ & $\begin{array}{c}\text { III } \\
\mathbf{( 2 0 1 8 - 2 0 2 0 )}\end{array}$ & \\
\hline Indiangrass & 8.9 & 10.1 & 14.9 & 11.3 \\
\hline Big Bluestem & 4.4 & 8.3 & 9.3 & 7.3 \\
\hline Columbus Grass & 11.4 & 14.9 & 18.0 & 14.8 \\
\hline Year average & 8.2 & 11.1 & 14.1 & 11.1 \\
\hline LSD05 (factor A) & 2.1 & 1.3 & 3.5 & 2.4 \\
\hline LSD05 (factor B) & - & - & - & 2.1 \\
\hline LSD05 (factor A and B) & - & - & - & 1.8 \\
\hline
\end{tabular}

Over the research years, the yield of Columbus Grass dry biomass increased from $11.4 \mathrm{t} / \mathrm{ha}\left(1^{\text {st }}\right.$ year) to $14.9 \mathrm{t} / \mathrm{ha}\left(2^{\text {nd }}\right.$ year $)$ to $18.0 \mathrm{t} / \mathrm{ha}$ $\left(3^{\text {rd }}\right.$ year). This indicator averaged $14.8 \mathrm{t} /$ ha over the years.

Columbus Grass produced the highest biomass yields, this indicator of Indiangrass was slightly lower, and Big Bluestem produced the lowest yields (Figure 5).

So, Columbus Grass produced the highest yield of both raw and dry biomass and Big Bluestem produced the lowest one during their longterm cultivation. Indiangrass had an intermediate (medium) value of this indicator.

\section{Model of artificial phytocenoses of energy crops}

We have modeled the component structure of energy plantation of energy crops to involve herbaceous energy crops in the phytocenosis.

The scheme for creating artificial phytocenoses and land reclamation using energy crops should be as follows (Figure 6).

The structure of sown areas provides for the placement of several strips of companion crops of energy plants (legumes are placed in row-spacing) on marginal lands. A field-protective belt with energy crops is laid along the perimeter of the field (Columbus Grass and Big Bluestem in combination). This achieves a semi-blown construction of the phytocenosis - the middle layer is occupied by Columbus Grass and the lower one is occupied by Big Bluestem. In this case, the maximum effect is achieved: the water regime of 


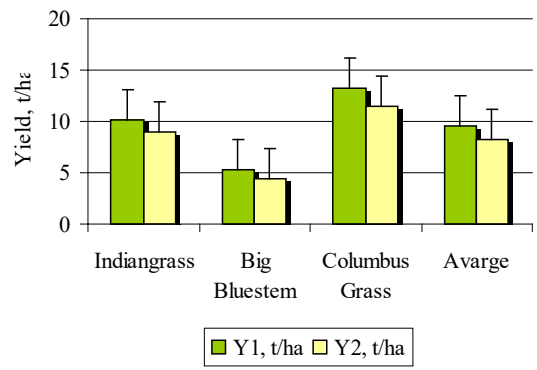

The first year of vegetation

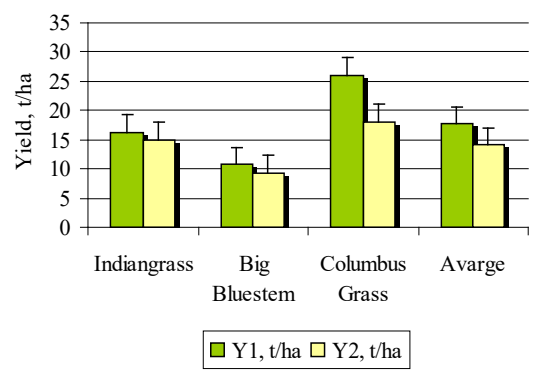

The third year of vegetation

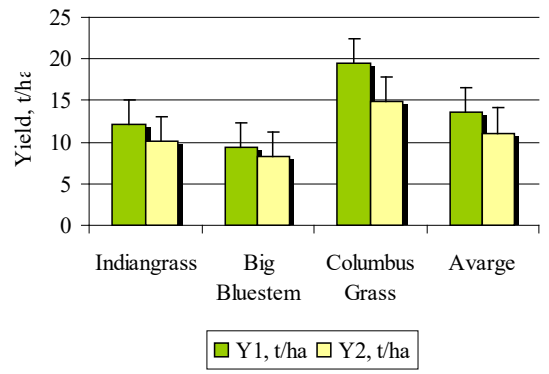

The second year of vegetation

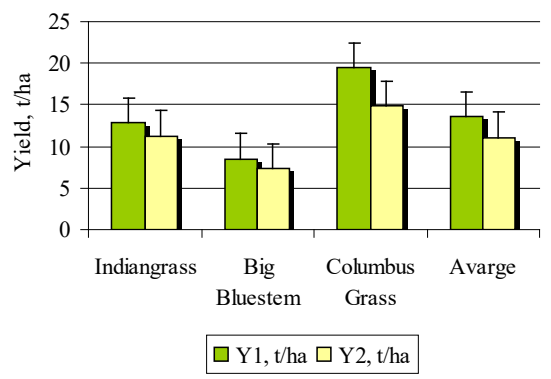

Average over the years

\section{Figure 5. Yield of raw and dry biomass of energy crops, over the research years and on average, 2016-2020}

Note: Y1 - yield of raw biomass, t/ha; Y2 - yield of dry biomass, t/ha

the field is improved (due to the retention of snow in winter), and air flows do not blow the top layer of soil out of the field.

The application of this scheme will result in reasonable development of agricultural techniques for biological reclamation of disturbed lands (ecological and adaptive elements of cultivation technology). These elements of agricultural technology include: various tillage practices, landscaping, preparation of seeds and planting material. The agronomic justification of energy crops sowing according to the developed scheme is important as well. Proper calculation of the seeding rates of seed or planting material will ensure the planned density of stems. Finally, after crops care, biomass is harvested. 


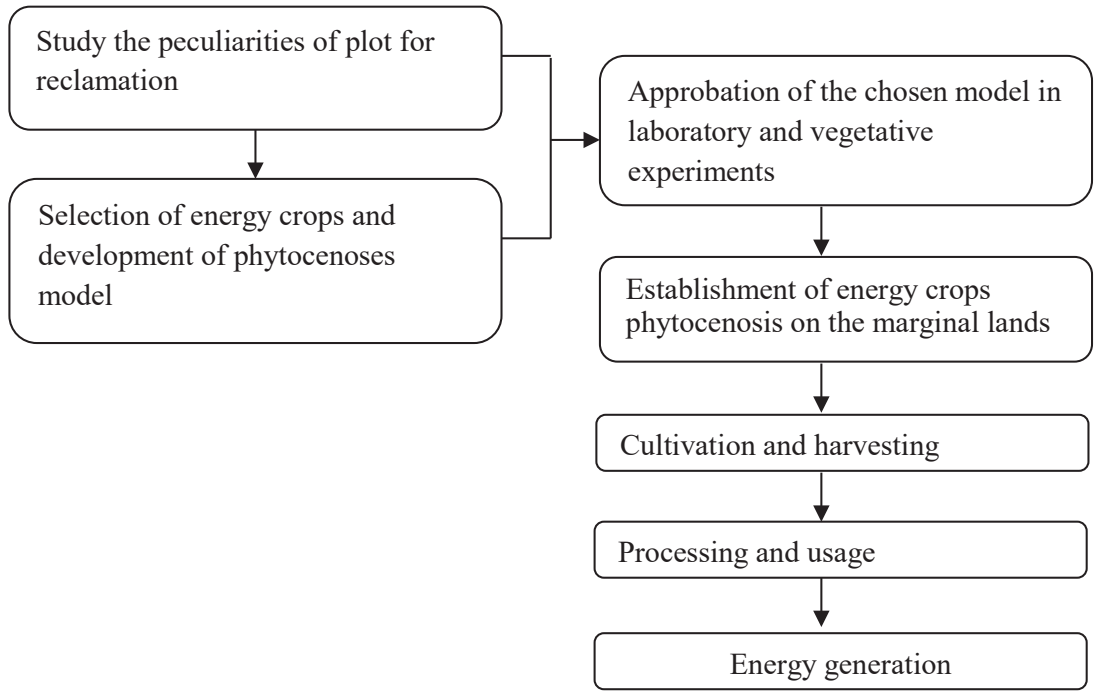

Figure 6. The scheme for creating artificial phytocenoses and land reclamation using energy crops

Therefore, to create artificial phytocenoses of energy crops, it is necessary:

- to study thoroughly the features of the plot for recultivation: landscape, agrochemical parameters of the soil, natural vegetation, etc.

- to select plants taking into account their compatibility in grass mixtures on the basis of laboratory and vegetation experiments,

- to place energy crops on the plot in strips together with legumes according to the developed model of phytocenoses,

- to place woody and herbaceous crops along the perimeter of the energy plantation. They will protect the main crops from the wind.

Thus, study and selection of energy plants for the creation of artificial phytocenoses with subsequent cultivation on reclaimed lands must be carried out on the basis of agri-environmental monitoring and justification. Furthermore, energy crops must be cultivated on the basis of ecological and adaptive technology elements, taking into account the defined territorial conditions. For the conditions of Ukraine, this complex will make it 
possible to reduce the negative impact on the environment as well as to obtain the stable yields of various biomass for its further processing and energy conversion.

\section{Energy assessment of energy crops cultivation}

We used the appropriate methodology in order to perform energy assessment of the efficiency of energy crops cultivation. The methodology included the following indicators: $\mathrm{B}$ - biomass yield, $\mathrm{t} / \mathrm{ha} ; \mathrm{B}_{\text {out }}-$ output of solid biofuel, t/ha; $\mathrm{E}_{\text {out }}$ - energy output, GJ/ha; Etot - total energy resource expenditures per 1 ha of crops, GJ/ha; EIT - energy intensity of production technology, $\mathrm{GJ} / \mathrm{t} ; \mathrm{C}_{\mathrm{ee}}-$ energy efficiency coefficient [65]. The energy intensity of energy crops biomass at a level of $16.5 \mathrm{MJ} / \mathrm{kg}$ was taken into account.

Energy efficiency of biomass production of studied energy crops is given in table 5 .

Table 5

Energy efficiency of biomass production of energy crops, 2016-2020

\begin{tabular}{|l|c|c|c|c|c|c|c|}
\hline \multirow{2}{*}{ Crop } & \multirow{2}{*}{ Year } & \multirow{2}{*}{$\begin{array}{c}\text { Yield, } \\
\mathbf{t} / \mathbf{h a}\end{array}$} & \multicolumn{6}{|c|}{ Indicators } \\
\cline { 4 - 8 } & & $\mathbf{B}_{\text {out }}$ & $\mathbf{E}_{\text {out }}$ & $\mathbf{E}_{\text {tot }}$ & $\mathbf{E I T}$ & $\mathbf{C}_{\text {ee }}$ \\
\hline \multirow{3}{*}{ Indiangrass } & 1 & 8.9 & 9.8 & 161.5 & 56.9 & 5.8 & 2.8 \\
\cline { 2 - 8 } & 2 & 10.1 & 11.1 & 183.3 & 57.7 & 5.2 & 3.2 \\
\cline { 2 - 8 } $\begin{array}{l}\text { Big } \\
\text { Bluestem }\end{array}$ & 3 & 14.9 & 16.4 & 270.4 & 62.4 & 3.8 & 4.3 \\
\cline { 2 - 8 } & 2 & 4.4 & 4.8 & 79.9 & 62.6 & 12.9 & 1.3 \\
\cline { 2 - 8 } & 3 & 9.3 & 9.1 & 150.6 & 59.5 & 6.5 & 2.5 \\
\hline \multirow{2}{*}{$\begin{array}{l}\text { Columbus } \\
\text { Grass }\end{array}$} & 1 & 11.4 & 10.2 & 168.8 & 66.8 & 6.5 & 2.5 \\
\cline { 2 - 8 } & 2 & 14.9 & 16.4 & 206.9 & 67.9 & 5.4 & 3.0 \\
\cline { 2 - 8 } & 3 & 18.0 & 19.8 & 326.7 & 68.5 & 3.5 & 4.8 \\
\hline
\end{tabular}

*Note: $\mathrm{B}_{\text {out }}-$ output of solid biofuel, t/ha; $\mathrm{E}_{\text {out }}-$ energy output, GJ/ha; $\mathrm{E}_{\text {tot }}-$ total energy resource expenditures per 1 ha of crops, GJ/ha; EIT - energy intensity of production technology, $\mathrm{GJ} / \mathrm{t} ; \mathrm{C}_{\mathrm{ee}}-$ energy efficiency coefficient.

The accumulation of total energy in products in an amount equal to or exceeding a level of total energy costs for production is a criterion of energy efficiency of biomass production. The threshold value of energy efficiency is achieved when the coefficient of energy efficiency is equal to or exceeds 1.0, which is an increase (Figure 7). 


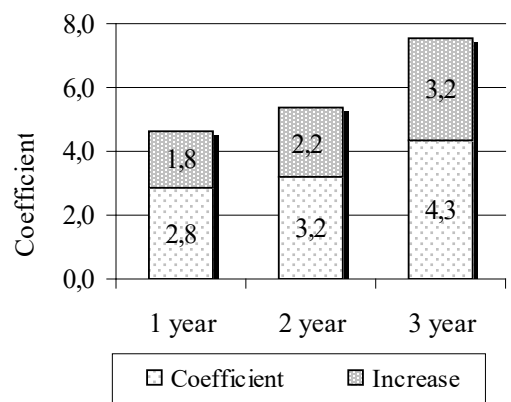

$\mathrm{a}$

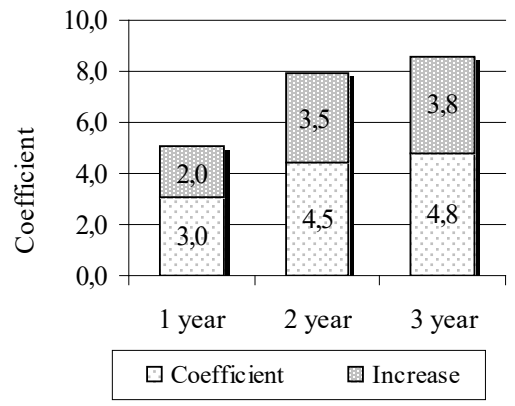

c

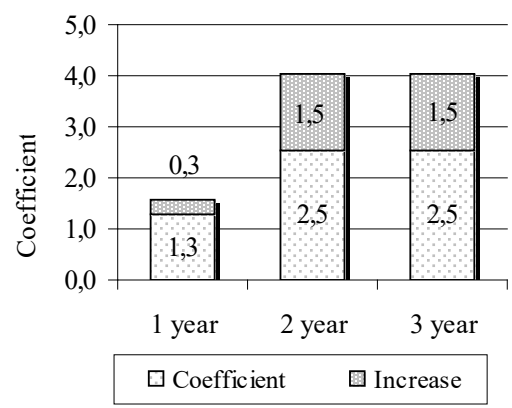

b

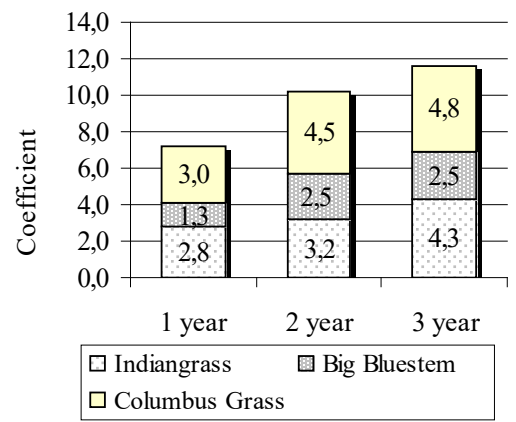

$\mathrm{abc}$

Figure 7. Coefficient of energy efficiency of growing energy crops: Indiangrass (a), Big Bluestem (b), Columbus Grass (c), 2016-2020

It is established that the coefficient of energy efficiency of biomass production of energy crops varied from 1.3 to 4.8 over the years of research. Accordingly, the increase for Kee was from 0.3 to 3.8. The coefficient of Indiangrass exceeded 3.0 from the second year, Columbus Grass coefficient from the first year, which is typical for the average efficiency of biomass production. Kee of Big Bluestem did not exceed 2.5 over the research years.

Taking into account the results of energy efficiency, we can recommend Indiangrass and Columbus Grass to be used for soil reclamation. Cultivation of these types of energy crops will enable farms to steadily obtain plant 
biomass and produce biofuel. It also provides an opportunity to earn extra income, as a result - payrise and improvement of workers welfare. In addition, this implies a gradual reduction of energy dependence of territorial communities.

By increasing the energy efficiency of energy crops biomass (Indiangrass and Columbus Grass), the average level of energy efficiency of biomass production is achieved. That is, their cultivation on marginal lands, taking into account the developed model, will reduce energy consumption, will enable to stabilize ecology and obtain the stable yields of plant biomass for its further processing and energy conversion.

\section{Conclusions}

1. In terms of plant height, Columbus Grass $(187.1 \mathrm{~cm})$ and Indiangrass $(143.5 \mathrm{~cm})$ were distinguished among all the studied energy crops, Big Bluestem had the lowest value $(67.0 \mathrm{~cm})$ according to this indicator.

2. Indiangrass (1.5 million units/ha) and Columbus Grass (1.9 million units/ha) provided the highest indicator of density of stems over the research years. The lowest indicator (0.7 million units/ha) was determined in Big Bluestem crop.

3. Over the research years, an increase in the trend of "raw" (green) biomass of Indiangrass from 10.1 to $16.2 \mathrm{t}$ /ha was noted and "dry" biomass from 8.9 to $14.9 \mathrm{t} / \mathrm{ha}$ was determined. This trend of perennial sorghum was from 13.2 to $26.0 \mathrm{t} / \mathrm{ha}$ and from 11.4 to $18.0 \mathrm{t} / \mathrm{ha}$, respectively. The variation of these indicators of Big Bluestem was the lowest: the yield of "raw" (green) biomass was from 5.3 to $10.7 \mathrm{t} / \mathrm{ha}$, "dry" biomass - from 4.4 to $9.3 \mathrm{t} / \mathrm{ha}$.

4. The developed model for the creation of artificial phytocenoses will allow land reclamation using energy crops based on agroecological monitoring and justification.

5. Cultivation of Columbus Grass and Indiangrass provided the highest coefficient of energy efficiency (at a level or more than 3.0), which is typical for average efficiency of biomass production.

Indiangrass and Columbus Grass are recommended to be grown in order to reclaim marginal lands and obtain sustainable plant raw materials. Big Bluestem is recommended to be grown only as a companion crop of stand of grass. The cultivation of energy crops on marginal lands must be 
carried out on the basis of ecological and adaptive technology elements, taking into account the defined territorial conditions. The proposed model for the creation of artificial phytocenoses will enable to stabilize ecology and simultaneously obtain the stable yields of plant biomass for its further processing and energy conversion.

\section{References:}

1. Biliavskyi Yu. V., Biliavska L. H. (2019) Analiz ahro-klimatychnykh ta hruntovykh umov Lisostepu Ukrainy dlia vyroshchuvannia silskohospodarskykh ta enerhetychnykh kultur [Analysis of agro-climatic and soil conditions of the ForestSteppe of Ukraine for growing agricultural and energy crops]. Optymalni enerhetychni systemy z urakhuvanniam naiavnoho potentsialu vidnovliuvanykh dzherel enerhii u Lisostepu Ukrainy: kolektyvna monohrafiia / Za zah. red. M. I. Kulyka, O. V. Kalinichenka. Poltava: PP “Astraia”, pp. 7-17. (in Ukrainian)

2. Polovyi A. M., Bozhko L. Yu. (2015) Vplyv klimatychnykh zmin na rezhym zvolozhennia vehetatsiinoho periodu v Ukraini [The impact of climate change on the humidification regime of the growing season in Ukraine]. Ukrainskyi hidrometeorolohichnyi zhurnal, no. 16, pp. 128-139 (in Ukrainian)

3. Kulyk M., Shokalo N., Dinets O. (2019) Morphometric indices of plants, biological peculiarities and productivity of industrial energy crops. Development of modern science: the experience of European countries and prospects for Ukraine: monograph / edited by authors. 3rd ed. Riga, Latvia: «Baltija Publishing», pp. 411-431.

4. Kulyk M. I., Padalka V. V. (2020) Rozvytok bioenerhetyky na osnovi roslynnoho enerhetychnoho resursu (na prykladi Poltavskoi oblasti) [Development of bioenergy based on plant energy resources (on the example of Poltava region)]. Upravlinnia stratehiiamy vyperedzhaiuchoho innovatsiinoho rozvytku: monohrafiia /za red. k.e.n., dotsenta N. S. Illiashenko. Sumy: Trytoriia, pp. 109-118. (in Ukrainian)

5. Nataliia Kutsokon, Lidiya Khudolieieva, Svitlana Los, Liliia Torosova, Natalia Vysotska (2020) Evaluation of poplar and willow clones on the experimental short rotation plantation in Kharkiv region: results of the second cultivation year. Plant Varieties Studying and Protection, 16(2): 182-190. DOI: https://doi.org/ 10.21498/2518-1017.16.2.2020.209238

6. Ministerstvo enerhetyky ta zakhystu dovkillia Ukrainy (2017) Ekolohichnyi pasport Poltavskoi oblasti Internet-resurs. Retrieved from: https://menr.gov.ua/files/ docs/eco_passport $/ 2017 / \%$ D0\%9F\%D0\%BE\%D0\%ВПолтавська_ЕкоПаспорт (accessed 5 April 2021)

7. Kulyk M. I., Kurylo V. L., Kalinichenko O. V., Galytska M. A. (2019) Plant energy resources: agroecological, economic and energy aspects. Monograf. $160 \mathrm{p}$.

8. D'omin Dmytro, Kulyk Maksym, Rozhko Ilona (2021) Agroecological fundamentals of creation of artificial phytocenoses of energy crops for recultivation. Innovative Approaches to Ensuring the Quality of Education, Scientific Research 
and Technological Processes: Series of monographs. 43 Faculty of Architecture, Civil Engineering and Applied Arts Katowice School of Technology /Edited by Magdalena Gawron-Łapuszek Yana Suchukova. Publishing House of University of Technology, Katowice, pp. 1035-1041.

9. Gumentyk M., Kharytonov M. (2018) Development and assessment of technologies of miscanthus and switchgrass growing in Forest-Steppe zone of Ukraine. Agriculture and Forestry, vol. 64, iss. 2, pp. 137-146. DOI: https://doi.org/ 10.17707/AgricultForest.64.2.10

10. Maroš Korenko, Volodymyr Bulgakov, Vasyl Kurylo, Maksym Kulyk, Alexander Kalinichanko, Yevhen Ihnatiev, Eva Matušeková (2021) Formation of Crop Yields of Energy Crops Depending on the Soil and Weather Conditions. Acta Technologica Agriculturae, vol. 24(1), pp. 41-47. DOI: https://doi.org/10.2478/ata-2021-0007

11. Kulyk M. I., Rakhmetov D. B., Rozhko I. I., Syplyva N. O. (2019) Vykhidnyi material prosa prutopodibnoho (Panicum virgatum L.) za kompleksom hospodarsko-tsinnykh oznak v umovakh tsentralnoho Lisostepu Ukrainy [The source material of millet rod (Panicum virgatum L.) on a set of economically valuable traits in the central forest-steppe of Ukraine]. Sortovyvchennia ta okhorona prav na sorty roslyn, vol. 15 , no. 4, pp. 354-364.

12. Kulyk M. I., Rozhko I. I., Syplyva N. O., Bozhok Yu. O. (2019) Ahrobiolohichni osoblyvosti formuvannia vrozhainosti ta yakosti nasinnia prosa prutopodibnoho [Agrobiological features of yield formation and quality of millet seeds]. Visnyk ahrarnoi nauky Prychornomoria, vol. 4(104), pp. 51-60. (in Ukrainian)

13. Kulyk M. I., Padalka V. V. (2020) Rozvytok bioenerhetyky na osnovi roslynnoho enerhetychnoho resursu (na prykladi Poltavskoi oblasti) [Development of bioenergy based on plant energy resources (on the example of Poltava region)]. Upravlinnia stratehiiamy vyperedzhaiuchoho innovatsiinoho rozvytku: monohrafiia / za red. k.e.n., dotsenta N. S. Illiashenko. Sumy: Trytoriia, pp. 109-118. (in Ukrainian)

14. Gorb Oleg, Kostenko Olena, Kulyk Maksym, at all. (2018) Energy crops: the link between education and science. Odnawialne Żródta Energii-teoria i praktyka: Monograph / Edited by Izabela Pietkun-Greber and Dariusz Suszanowicz. Uniwersytet Opolski, Opole. Tom 3, 9-36.

15. Pysarenko P. V., Kurylo V. L., Kulyk M. I. (2017) Ahrobiomasa ta fitomasa enerhetychnykh kultur dlia vyrobnytstva biopalyva [Agrobiomass and phytomass of energy crops for biofuel production]. Rozrobka ta vdoskonalennia enerhetychnykh system z urakhuvanniam naiavnoho potentsialu alternatyvnykh dzherel enerhii: kolektyvna monohrafiia / za red. O. O. Horba, T. O. Chaiky, I. O. Yasnolob. P.: TOV NVP «Ukrpromtorhservis», pp. 258-266. (in Ukrainian)

16. Kulyk Maksym, Kalinichenko Oleksandr, Dekovetz Vitalii (2020) Efficiency of energy crops cultivation for business development in Ukraine. Organization and management in the services' sphere on selected examples / Editors: Tetyana Nestorenko, Tadeusz Pokusa. Monograph. Opole: The Academy of Management and Administration in Opole, pp. 36-45. ISBN 978-83-66567-02-3. URL: http://pedagogika.wszia.opole.pl/ebook/3_2020.pdf 
17. Fedirets O. V., Kalinichenko O. V. (2019) Formation of agricultural enterprise energy saving mechanism. Modern Economics, vol. 9, pp. 153-159.

18. Kulyk M., Galytskaya M., Plaksiienko I., Kocherga A., Mishchenko O. (2020) Switchgrass and lupin as phytoremediation crops of contaminated soil. International Multidisciplinary Scientific GeoConference: SGEM. Bulgaria, Sofia, т. 20, vol. 5.1: 779-784. DOI: $10.5593 /$ sgem2020/5.1/s20.098

19. Kulyk M., Galytska M., Samoylik M., \& Zhornyk, I. (2019) Phytoremediation aspects of energy crops use in Ukraine. Agrology, vol. 2(1), 65-73. DOI: https://doi.org/10.32819/2617-6106.2018.14020

20. Maksym Kulyk, Vasyl Kurilo, Natalia Pryshliak, Viktor Pryshliak (2020) Efficiency of Optimized Technology of Switchgrass Biomass Production for Biofuel Processing. Journal of Environmental Management and Tourism, [S.1.], vol. 11, no. 1, pp. 173-185. DOI: https://doi.org/10.14505//jemt.v11.1(41).20

21. Kulyk M., Galytskaya M., Plaksiienko I., Kocherga A., Mishchenko O. (2020) Switchgrass and lupin as phytoremediation crops of contaminated soil. International Multidisciplinary Scientific GeoConference: SGEM. Bulgaria, Sofia, т. 20, vol 5.1: 779-784. DOI:10.5593/sgem2020/5.1/s20.098

22. Rozhko I., Kulyk M. (2021) The use energy crops in order to improve marginal lands. The 5-th International scientific and practical conference - Priority directions of science and technology development (January 24-26, 2021) SPCSciconf.com.ua, Kyiv, Ukraine, pp. 29-34.

23. Schirenko A. I. (2010) Tehnologiya rastitelnyih melioratsiy rekultiviruemyih zolootvalov na primere vtoroy sektsii zolootvala Novocherkasskoy GRES [The state of grassy vegetation and the accumulation of heavy metals by plants growing under conditions of man-made soil pollution]: avtoreferat dissertatsii na soiskanie uchYonoy stepeni kandidata selskohozyaystvennyih nauk. Spetsialnost 06.01.02 - «Melioratsiya, rekultivatsiya i ohrana zemel». Novocherkassk, p. 24. (in Ukrainian)

24. Batova Yu. V., Kaznina N. M., Titov A. F., Laydinen G. F. (2014) Sostoyanie travyanistoy rastitelnosti i nakoplenie tyazhelyih metallov rasteniyami, proizrastayuschimi $\mathrm{v}$ usloviyah tehnogennogo zagryazneniya pochvyi [The state of herbaceous vegetation and the accumulation of heavy metals by plants growing in conditions of technogenic soil pollution]. Vestnik Tambovskogo universiteta. Seriya: Estestvennyie i tehnicheskie nauki, vol. 19, no. 5, pp. 1642-1645. (in Ukrainian)

25. Kulyk M. I., Kurylo V. L. (2017) Enerhetychni kultury dlia vyrobnytstva biopalyva: dovidnyk [Energy culture for biofuel production]. Poltava: RVV PDAA, 74 p. (in Ukrainian)

26. Kulyk M. I., Kosenko S. M. (2019) Zbilshennia vrozhainosti miskantusu hihantskoho na osnovi adaptyvnykh elementiv tekhnolohii vyroshchuvannia [Increasing the yield of giant miscanthus based on adaptive elements of cultivation technology]. Abstracts of I International Scientific and Practical Conference Lviv, Ukraine, 28-29 October, pp. 16-19. (in Ukrainian)

27. Ashworth A. J., Allen F. L., Keyser P. D., at all. (2015) Switchgrass yield and stand dynamics from legume intercropping based on seeding rate and harvest management. Journal of Soil and Water Conservation, 70(6): 374-384. 
28. Yeshchenko V. O., Kopytko P. H., Opryshko V. P. [ta in.] (2005) Osnovy naukovykh doslidzhen $\mathrm{v}$ ahronomii [Fundamentals of scientific research in agronomy]. Kyiv: Diia, 288 p. (in Ukrainian)

29. Kulyk M. I., Halytska M. A., Domin D. H. (2018) Ahrobiomasa ta enerhetychni kultury dlia vyrobnytstva biopalyva: naukovo-praktychni rekomendatsii [Agrobiomass and energy crops for biofuel production: scientific and practical recommendations]. Dnipro. (in Ukrainian)

30. Pysarenko P. V., Horb O. O., Kulyk M. I., ta in. (2017) Naukovo-praktychni rekomendatsii do vyroshchuvannia enerhetychnykh kultur ta vykorystannia fitomasy [Scientific and practical recommendations for growing energy crops and the use of phytomass]. Poltava. (in Ukrainian)

31. Kulyk M. I. (2015) Menedzhment vyroshchuvannia enerhetychnykh kultur dlia vyrobnytstva biopalyva: naukovo-praktychni rekomendatsii. Poltava: Poltavska DAA. (in Ukrainian)

32. Kulyk M. I., Halytska M. A. (2018) Alhorytm obrakhunku dostupnoho potentsialu ahrobiomasy ta fitomasy enerhetychnykh kultur dlia vyrobnytstva biopalyva: naukovo-metodychni rekomendatsii [Algorithm for calculating the available potential of agrobiomass and phytomass of energy crops for biofuel production: scientific and methodological recommendations]. Poltava. (in Ukrainian)

33. Kulyk M. I., Rakhmetov D. B,. Kurylo V. L. (2017) Methodology of conducting field and laboratory researches with switchgrass (Panicum virgatum L.). Poltava. (in Ukrainian)

34. Borovikov V. P. (2003) Statistica. Iskusstvo analiza dannyih na kompyutere: dlya professionalov [The Art of Computer Data Analysis: For Professionals]. SPb.: Piter, 688 p. (in Russian)

35. Ermantraut E. R., Prysiazhniuk O. I., Shevchenko I. L. (2007) Statystychnyi analiz ahronomichnykh doslidnykh danykh v paketi Statistica - 6: Metodychni vkazivky [Statistical analysis of agronomic research data in the package Statistica - 6: Methodical instructions]. Kyiv. (in Ukrainian)

36. Kalinchenko O. V., Kulyk M. I. (2019) Naukovyi tvir «Metodychni zasady otsinky enerhetychnoi efektyvnosti vyroshchuvannia enerhetychnykh kultur v umovakh Lisostepu Ukrainy» [Scientific work «Methodological principles for assessing the energy efficiency of growing energy crops in the Forest-Steppe of Ukraine»]. Svidotstvo pro reiestratsiiu avtorskoho prava na tvir no. 93177 vid 18.10.2019. (in Ukrainian)

37. Domin D. H., Kulyk M. I. (2021) Perspektyvni maloposhyreni enerhetychni kultury dlia otrymannia biolohichnoi syrovyny ta rekultyvatsii gruntiv [Promising uncommon energy crops for the production of biological raw materials and soil reclamation]. Orhanizatsiia diialnosti v ahropromyslovomu kompleksi ta aktualni pytannia veterynarii: materialy I mizhnarodnoi spetsializovanoi naukovoi konferentsii, m. Khmelnytskyi, 5 bereznia, 2021 r. / Mizhnarodnyi tsentr naukovykh doslidzhen. Vinnytsia: Yevropeiska naukova platforma, pp. 7-9. (in Ukrainian)

38. Henning, J. (1993) Big bluestem, Indiangrass, and switchgrass. Bulletin G4673. University of Missouri Cooperative Extension. University of Missouri. Columbia, MO. Internet-resurs. Retrieved from: https://extension.missouri.edu/ publications/g4673 (accessed 5 April 2021). 
39. Delucia E. H., Heckathorn S. A. and T. A. Day (1992) Effects of soil temperature on growth, biomass allocation and resource acquisition of Andropogon gerardii Vitman. New Phytol., 120: 543-549.

40. Forwood J. R., and M. M. Magai (1992) Clipping frequency and intensity effects on big bluestem yield, quality, and persistence. J. Range Manage., 45: $554-559$.

41. McKone M. J., C. P. Lund and J. M. O’Brien (1998) Reproductive biology of two dominant prairie grasses (Andropogon gerardii and Sorghastrum nutans, Poaceae): male-biased sex allocation in wind-pollinated plants. Am. J. Bot., 85: 776-783.

42. Dremov P. A. (2005) Zavisimost strukturyi urozhaya travyi Kolumbyi ot normyi vyiseva [Dependence of the structure of the yield of Columbus grass on the seeding rate]. Problemyi razvitiya selskogo hozyaystva tsentralnogo chernozemya. Kurskaya GSHA, pp. 166-167. (in Russian)

43. Romanchuk L. D., Vasyliuk T. P., Mozharivska I. A. (2013) Rist i rozvytok sorho bahatorichnoho v umovakh Polissia Ukrainy [Growth and development of perennial sorghum in Polissya Ukraine]. Visnyk Zhytomyrskoho natsionalnoho ahroekolohichnoho universytetu, vol. 2(1), pp. 3-8. (in Ukrainian)

44. Opys ta kharakterystyka sorho bahatorichne [Description and characteristics of perennial sorghum]. Retrieved from: https://agrarii-razom.com.ua/plants/ sorgo-bagatorichne (accessed 5 April 2021).

45. Kurylo V. L., Rakhmetov D. B., Kulyk M. I. (2018) Biolohichni osoblyvosti ta potentsial urozhainosti enerhetychnykh kultur rodyny tonkonohovykh $\mathrm{v}$ umovakh Ukrainy [Biological features and yield potential of energy crops of the thin-legged family in the conditions of Ukraine]. Visnyk Poltavskoi derzhavnoi ahrarnoi akademii, vol. 1(88), pp. 11-17. (in Ukrainian)

46. Rudnyk-Ivashchenko O. I. (2009) Proso. Osoblyvosti biolohii, fiziolohii, henetyky: monohrafiia [Millet. Features of biology, physiology, genetics: monograph]. Instytut tsukrovykh buriakiv, UAAN. Kyiv: Kolobih, 160 p. (in Ukrainian)

47. Zinchenko O. I., Salatenko V. N., Bilonozhko M. A. (2001) Roslynnytstvo: Pidruchnyk [Crop production: a textbook] / Za red. O. I. Zinchenka. Kyiv: Ahrarna osvita, 591 p. (in Ukrainian)

48. Roik M. V., Kurylo V. L., Humentyk M. Ya., ta in. (2010) Enerhetychni kultury dlia vyrobnytstva biopalyva [Energy crops for biofuel production]. Naukovi pratsi Poltavskoi derzhavnoi ahrarnoi akademii. Poltava, t. 7. pp. 12-15. (in Ukrainian) 